Article

\title{
Evaluating and Prioritizing the Green Supply Chain Management Practices in Pakistan: Based on Delphi and Fuzzy AHP Approach
}

\author{
Yuanyuan Zhou ${ }^{1, *}, \mathrm{Li} \mathrm{Xu}^{2,3}$ and Ghulam Muhammad Shaikh ${ }^{4}$ (D) \\ 1 Nanjing Institute of Technology, Nanjing 211167, China \\ 2 College of Finance, Jiangsu Vocational Institute of Commerce, Nanjing 211168, China; \\ shirely.xu@nuaa.edu.cn \\ 3 College of Economics and Management, Nanjing University of Aeronautics and Astronautics, \\ Nanjing 211106, China \\ 4 Department of Computer Science, Bahria University, Karachi Campus 75260, Pakistan; \\ ghulammuhammad.bukc@bahria.edu.pk \\ * Correspondence: jgxy@njit.edu.cn
}

Received: 12 October 2019; Accepted: 25 October 2019; Published: 1 November 2019

\begin{abstract}
Nowadays, green supply chain management (SCM) practices are increasing among firms to adopt green practices and reduce the negative effects of supply chain operations on the environment. Firms such as manufacturing, mining, and agriculture have to improve their capacity in green SCM practices because environmental regulations force them to consider these issues. However, green practices are new and require comprehensive study to determine this problem. This study has taken the case of three garment manufacturing firms for the evaluation of green SCM practices in the context of Pakistan. The green SCM requires multi-dimensional techniques; therefore, fuzzy-based multi-criteria decision analysis approaches must be adopted while assessing green SCM practices of firms. This is because fuzzy-based methods obtain a significant solution for complex, vague, and uncertain multi-attribute problems in fuzzy environment. Therefore, in this study, a hybrid decision model comprised of Delphi, and Fuzzy Analytical Hierarchy Process (AHP) methodologies is proposed for assessing the green SCM practices of firms in terms of green design, green purchasing, green production, green warehousing, green logistics, and reverse logistics. The Fuzzy AHP method results reveal that "green purchasing," "green design," and "green production" are ranked the most important green indicators. Further, results reveal the ranking of manufacturing firms (alternatives) in the context of green SCM practices. This study shall help industries to focus on green SCM practices and adopt the green manufacturing process.
\end{abstract}

Keywords: green supply chain management practices; green indicators; manufacturing firms; Delphi; Fuzzy AHP; Pakistan

\section{Introduction}

Nowadays, green SCM has become a very popular practice because of increasing awareness of environmental protection and sustainability. Industries are obliged to take into account green practices to reinforce their green image and for the betterment of the environment [1]. In this context, various firms such as service, manufacturing, agriculture, and mining industries carry out green SCM practices in many countries of the world [2]. The firms are responsible for their practices in preventing hazardous environmental activities such as overflowing waste and raw material extraction from sites; thus, firms should put more environmental standards and regulations on their activities. The main objectives of green SCM are to achieve sustainable development goals by minimizing or eliminating 
the environmental damages created by supply chain practices. Therefore, green SCM activities make it important and possible for firms to restructure their design, purchase, production, warehousing, and logistics operations. Further, reverse logistics is a key attribute of green SCM in capturing value from used products and materials or to appropriately recycle them [3].

Moreover, despite the popularity and implementation of green SCM practices in many countries, still, there is room to put forward implications in terms of both practical and research [4]. However, several motivations are reported in the previous studies for firms to implement green SCM practices $[5,6]$. From these previous studies, it has been identified that some firms implement green SCM based on customer satisfaction and expectations, while some firms adopt green practices for fulfilling environmental regulations. The current globalization has forced policymakers to adopt sustainable activities such as environmental, social, and economic dimensions [7]. Therefore, it is important to involve industrial value creation for the sustainable manufacturing process. The various studies have pointed out the importance of the fourth industrial revolution (so-called Industry 4.0) based on sustainability [8-12]. Nowadays, by the adoption of Industry 4.0, firms are liable to incorporate the triple bottom line sustainability issues for sustainable industrial value creation; therefore, in a previous study, the authors recommended several important dimensions along with triple bottom line dimensions for sustainable industrial value creation for industrial Internet of Things [13]. In another study, an assessment of the economic, ecological and social potential for industrial value creation in Industry 4.0 is qualitatively assessed from a macro and micro perspective, and, the study indicates that the industrial value creation has a positive contribution to sustainable development [14].

It is a matter of fact that firms or managers have to assess their green SCM practices and performances. However, in the process and evaluation of green SCM practices, it has always been considered as a major problem for selecting optimal indicators for firms' development and implementation in greener SCM operations. Because the decision problem is often very complex and includes vagueness, this study aims to propose an assessment approach for green SCM practices in the context of manufacturing firms in Pakistan. Therefore, Multi-Criteria Decision Making (MCDM) methods can be considered as very significant in minimizing the problem under fuzzy environment [15-18]. This study contributes to obtaining the most important green indicators for the evaluation of green SCM practices. Secondly, a decision model is proposed, which uses Delphi and Fuzzy Analytical Hierarchy Process (AHP) methodologies. In fact, the Delphi and AHP methods have been used together in various studies under fuzzy environment [19-21]. However, in the present study, a decision model is used in the perspectives of green SCM practices in the context of Pakistan. The analysis of the decision model would help managers and governments to evaluate this decision problem.

The main objective of this study is to develop a comprehensive set of green indicators to assess the SCM practices of firms using the Delphi and Fuzzy AHP method. This study is attempting to investigate green SCM indicators with respect to the manufacturing firms of Pakistan. Moreover, this is the first work to evaluate the green SCM practices using the Fuzzy AHP approach. The Delphi method is employed to determine and refine the most important green indicators based on expert's feedback. Then, the Fuzzy AHP method is used to evaluate and rank the significant green indicators (criteria), sub-indicators (sub-criteria), and manufacturing firms (alternatives) from the perspective of green supply chain practices. Also, these green indicators can be employed as benchmarking tools for analyzing the firms' green SCM activities.

The remaining sections of the study are organized as follows: Section 2 presents the related studies and proposes the green indicators for supply chain operations. Section 3 presents the proposed decision framework for the study. Section 4 clarifies the results and discussion. Finally, Section 5 provides the conclusion and managerial implications. 


\section{Related Studies}

Green SCM is a growing topic of interest in professional and academic circles, focused on green process enhancement, reverse logistics or waste reduction, increase in the product life cycle quality, and decrease in harmful environmental activities [22]. Green SCM emphasizes green activities, which are thoroughly related to sustainable environmental practices [23]. Meanwhile traditional SCM practices are hazardous to the environment, such as raw material production, distribution, and material waste, which can create a bad impact on the environment and also a source of pollution. Therefore, to protect the environment, it is essential to take into account green practices such as green manufacturing, green packaging, and reverse logistics in overall SCM operations [24]. Various countries have planned to implement the environmental standards and regulations for the industries to protect the environment from unwanted activities. These standards require industries to adopt green and environmentally friendly strategies in the entire SCM activities for sustainable environmental, economic, and social development.

In previous studies, the various green-based SCM activities have been determined with different aims and objectives. The Multi-Criteria Decision Making (MCDM) based approaches are often used to determine the feasible options for implementation of green SCM activities in the firms. MCDM is a branch of operations research methods to support turning the multi-faceted decision-making problem into a tiny problem [25]. Mirko et al. [26] have conducted a literature survey on sustainability engineering issues using MCDM applications from 2008-2018; the findings of the study present that MCDM methods are very suitable in solving sustainability decision problems. MCDM greatly helps in structuring and prioritizing the decision problem; it supports decision-makers to analyze, select, and rank alternatives based on the evaluation of various criteria of the decision problem [27]. This study evaluates the green supply chain management (SCM) practices in the perspectives of Pakistani manufacturing firms.

\subsection{Application of MCDM Approaches in Green Supply Chain Management Practices}

The MCDM approaches are widely suitable and significant in evaluating green SCM decision problems, such as Analytical Hierarchy Process (AHP), Decision Making Trial and Evaluation Laboratory (DEMATEL), Technique for Order of Preference by Similarity to Ideal Solution (TOPSIS), Analytic Hierarchy Process (ANP), Linear Programming, and Fuzzy Programming. These approaches provide direction in shifting toward sustainable and green SCM operations, which helps in making the environmentally sustainable. Table 1 summarizes the MCDM methods used in green SCM practices.

It is identified that there are various studies relating to the adoption of green SCM using MCDM methods. This study contributes further by developing a hybrid decision methodology comprised of a Delphi and Fuzzy AHP to evaluate and rank the green SCM practices in the context of Pakistani manufacturing firms.

\subsection{Proposed Green Indicators for Supply Chain Practices}

This study identifies several important green indicators for implementing green SCM practices. These green indicators are considered as a supporting tool for supply chain activities. In this study, a comprehensive set of literature reviews has been analyzed to identify the important indicators from the perspective of green supply chain practices. Thus, the six green indicators and twenty-two sub-indicators have been identified after a thorough literature review. These green indicators are: green design (G1), green purchasing (G2), green production (G3), green warehousing (G4), green logistics (G5), and reverse Logistics (G6). Table 2 summarizes the green SCM indicators and sub-indicators. 
Table 1. Summary of literature on evaluation of green supply chain management (SCM) practices.

\begin{tabular}{|c|c|c|c|c|}
\hline The Focus of the Study & Findings of the Study & Method & Year & Reference \\
\hline $\begin{array}{l}\text { Assessing the success factors to adopt green SCM in the } \\
\text { manufacturing industries of India }\end{array}$ & $\begin{array}{l}\text { The findings show that global competition, organizational structure, and } \\
\text { government are the most important factors for successfully implementing } \\
\text { green SCM practices }\end{array}$ & AHP & 2016 & [28] \\
\hline $\begin{array}{l}\text { Proposing a sustainable development methodology for mining } \\
\text { industries }\end{array}$ & $\begin{array}{l}\text { The results present that top management commitment, and initial } \\
\text { environmental review are the two main criteria for developing a } \\
\text { sustainable development framework for industries }\end{array}$ & AHP & 2015 & [29] \\
\hline Identify and evaluate the critical factors in green SCM practices & $\begin{array}{l}\text { The findings indicate that environmental policy and top management } \\
\text { support for green SCM are both crucial factors in firm involvement, which } \\
\text { should be ranked in the highest preference when green SCMS practices are } \\
\text { to be adopted. Further, green purchasing is the most important factor in } \\
\text { supply chain operations }\end{array}$ & DEMATEL & 2015 & [30] \\
\hline $\begin{array}{l}\text { Selecting and analyzing the green suppliers based on green SCM } \\
\text { practices in the Brazilian electronics company }\end{array}$ & $\begin{array}{l}\text { The findings of the study show that the significant factors are the } \\
\text { commitment of senior management to green SCM and product designs } \\
\text { that reduce, reuse, and recycle the material }\end{array}$ & Fuzzy TOPSIS & 2014 & [2] \\
\hline $\begin{array}{l}\text { Evaluating the close-loop or open hierarchical structures in green } \\
\text { SCM practices }\end{array}$ & $\begin{array}{l}\text { The research findings reveal that supplier involvement and process control } \\
\text { are the two most important aspects for close-loop hierarchical structure in } \\
\text { green SCM }\end{array}$ & Fuzzy ANP & 2014 & [32] \\
\hline Performance evaluation of green supply chain management & $\begin{array}{l}\text { The study indicates that green design, green logistics, and green } \\
\text { transformation are the most significant drivers for evaluating the green } \\
\text { SCM activities of the firm }\end{array}$ & $\begin{array}{l}\text { Fuzzy DEMATEL, Fuzzy } \\
\text { ANP, and Fuzzy TOPSIS }\end{array}$ & 2016 & [34] \\
\hline $\begin{array}{l}\text { Assessing the green supply chain management practices of an } \\
\text { industry }\end{array}$ & $\begin{array}{l}\text { The findings of this research show that green purchasing, green design, } \\
\text { and green marketing are the most optimal criteria for assessing the } \\
\text { performances of firms in transforming green SCM practices }\end{array}$ & $\begin{array}{l}\text { Intuitionistic Fuzzy } \\
\text { Numbers Model }\end{array}$ & 2018 & [35] \\
\hline $\begin{array}{l}\text { Factors Affecting Green SCM practices of the Thai Auto Parts } \\
\text { Industry }\end{array}$ & $\begin{array}{l}\text { The results of the study present that green procurement is the most optimal } \\
\text { factor, followed by green transportation, and green manufacturing for } \\
\text { implementing green SCM practices }\end{array}$ & $\begin{array}{l}\text { Factor Analysis and } \\
\text { Multiple Linear } \\
\text { Regression Analysis }\end{array}$ & 2016 & [36] \\
\hline
\end{tabular}


Table 2. Green supply chain management indicators and sub-indicators.

\begin{tabular}{llc}
\hline \multicolumn{1}{c}{ Indicator } & \multicolumn{1}{c}{ Sub-Indicator } & Reference \\
\hline Green design (G1) & Eco-design products (G11) & {$[1,2,37]$} \\
& Reduce the use of hazardous products (G12) & {$[18,38]$} \\
& Reduce the consumption of materials (G13) & {$[15,39]$} \\
& Reuse and recycle the product (G14) & {$[15,38]$} \\
\hline Green purchasing (G2) & Select the eco-friendly supplier (G21) & {$[2,40]$} \\
& Purchase of eco-friendly raw materials (G22) & {$[41,42]$} \\
& Pushing supplier to take eco-friendly actions (G23) & {$[43]$} \\
\hline Green production (G3) & Cleaner production (G31) & {$[38,44]$} \\
& Lean production (G32) & {$[45]$} \\
& Reduce the environmental impact on operations (G33) & {$[2,42]$} \\
& Reduce the amount of a scrap of the product (G34) & {$[42,46]$} \\
\hline Green warehousing (G4) & Eco-packaging (G41) & {$[45,47]$} \\
& Reduce the inventory levels (G42) & {$[42,49]$} \\
& Sale of excess inventories (G43) & {$[2,49]$} \\
\hline Sale of scrap materials (G44) & {$[5,50]$} \\
& Reduce fuel consumption (G51) & {$[51]$} \\
\hline Reverse Logistics (G6) & Using eco-friendly transportation (G52) & {$[44]$} \\
\hline & Eco-friendly distribution (G53) & {$[42,52]$} \\
& Develop environmental management system (G61) & {$[52]$} \\
& Use of alternative energy sources (G62) & {$[1,38]$} \\
& Recycling of end-of-life products (G63) & {$[52]$} \\
\hline
\end{tabular}

It is identified that MCDM approaches are widely used in the implementation of green SCM practices. These approaches are considered very significant in solving complex decision problems. To the best of the authors' knowledge, this is a very first attempt to investigate green supply activities from the perspective of Pakistan. In the present study, a Delphi and Fuzzy AHP method has been used to evaluate the green SCM practices of manufacturing firms of Pakistan.

\section{Research Methodology}

This study uses the Delphi and Fuzzy AHP methods to determine the important indicators and sub-indicators for evaluating the green SCM practices in Pakistan. Firstly, this study assesses inclusive literature to find out the important green indicators and sub-indicators. Then, a Delphi method is employed to finalize the green indicators in the context of Pakistan. Finally, the Fuzzy AHP method is used to determine the weights and ranking of green indicators (main criteria), sub-indicators (sub-criteria), and green activities of three garment manufacturing firms (alternatives) for successful adoption of green SCM practices. Ten experts participated during the Delphi and Fuzzy AHP method; the consulted experts were knowledgeable about green practices in SCM. These experts included three research fellows, three university professors, two stakeholders, and two government institute analysts. Figure 1 presents the research methodology of the present study. 


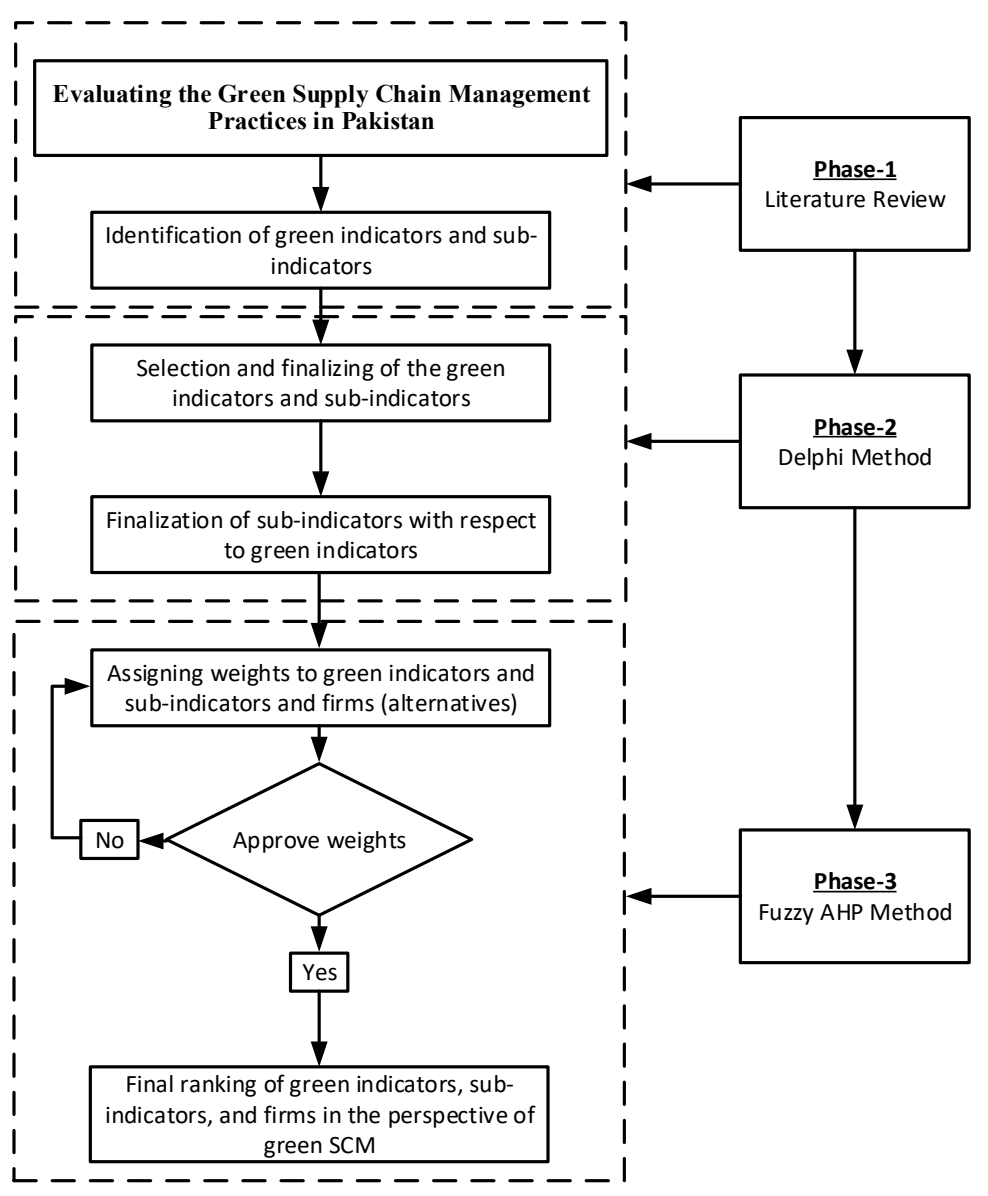

Figure 1. Decision methodology of the study.

\subsection{Delphi Method}

In this study, a Delphi approach is applied to finalize the green SCM indicators and sub-indicators for the adoption of green initiatives in the manufacturing firms of Pakistan. The main purpose of the Delphi method is to collect experts' opinions about any decision problem through semi-structured interviews, group discussions, and questionnaires [53]. In this method, the professional and relevant field experience experts share their opinion, ideas, knowledge, and expertise to make mutual understanding regarding the problem $[54,55]$. There are various steps involved in the Delphi process, which are comprised of: the selection of experts, the first round of questionnaire survey, the second and third round of the survey, and this process is continued or repeated until the experts research mutual consent [56]. This method does not have restrictions on the number of experts for providing feedback to any decision problem. Different studies have proposed different numbers of experts and rules for the validation of the data. However, a minimum of 9 and 18 experts should be involved in the decision-making process of the Delphi method [57]. Therefore, in this study, ten experts were consulted and participated in providing meaningful feedback about the decision problem. The questionnaire survey to these experts was sent through a webmail service, and each of the experts was asked to assign weights in the survey instrument using a Likert point scale between 1 and 5 (not at all important and extremely important). The survey instrument is attached in the Appendix A.

\subsection{Fuzzy Analytical Hierarchy Process Method}

AHP is a very significant method of MCDM [57]. This method is a four steps hierarchal approach of MCDM, which is used to rank the criteria, sub-criteria, and alternatives according to the particular goal of the decision problem [58]. However, in this study, the Fuzzy based AHP is employed to spoil the decision problem into a very small problem. This is because the fuzzy set theory helps in solving 
the incomplete information and immeasurable problem under fuzzy environment [59]. The pairwise comparison is then operated in a matrix using TFNs [60], to evaluate and prioritize the green SCM practices in Pakistan. Table 3 presents the TFNs rating scale employed in the present study.

Table 3. Linguistic variable and Triangular Fuzzy Numbers (TFNs) [61].

\begin{tabular}{lll}
\hline Number & Linguistic Variable & TFNs \\
\hline 1 & Equally significant & $(1,1,1)$ \\
2 & Equally to average significant & $(1,2,3)$ \\
3 & Averagely significant & $(2,3,4)$ \\
4 & Averagely to strongly significant & $(3,4,5)$ \\
5 & Strongly significant & $(4,5,6)$ \\
6 & Strongly to very strongly significant & $(5,6,7)$ \\
7 & Very strongly significant & $(6,7,8)$ \\
8 & Very strongly to extremely significant & $(7,8,9)$ \\
9 & Extremely significant & $(9,9,9)$ \\
\hline
\end{tabular}

Gogus and Boucher [62] proposed an approach to calculate the inconsistency ratio of fuzzy pairwise comparison matrices. The steps of Fuzzy AHP are given below:

Step 1: Transform a fuzzy triangular matrix into two independent matrices. At this step, a fuzzy triangular matrix is divided into two matrices, assuming that the triangular fuzzy number is presented as follows.

$$
X_{i}=\left(l_{i}, m_{i}, u_{i}\right)
$$

Then, the first matrix can be created by middle numbers of the fuzzy triangular matrix, that is:

$$
X_{m}=\left[x_{i j m}\right]
$$

The second matrix can be created by the geometric mean of the upper and lower bounds of the fuzzy triangular matrix, that is:

$$
X_{g}=\left[\sqrt{x_{i j u} x_{i j l}}\right]
$$

Step 2: Calculate the weight vector based on the Saaty method and calculation of lambda max ( $\lambda$ max). Step 3: Calculate the consistency index (CI) for each matrix; the CI can be computed based on the following equation:

$$
\begin{aligned}
& C I_{m}=\frac{\lambda_{\max }^{m}-n}{n-1} \\
& C I_{g}=\frac{\lambda_{\max }^{g}-n}{n-1}
\end{aligned}
$$

Step 4: Calculate the consistency ratio (CR) of the matrices. For CR, the consistency index (CI) of each matrix is divided by its random index (RI).

$$
\begin{gathered}
C R_{m}=\frac{C I_{m}}{R I_{m}} \\
C R_{g}=\frac{C I_{g}}{R I_{g}}
\end{gathered}
$$

The matrices are to be considered consistent if the values of $C R_{m}$ and $C R_{g}$ are less than 0.1; however, if the range surpasses 0.1 , then it does not provide significant results. Table 4 shows the values of the RI for each matrix of the Gogus and Boucher method.

The accomplishment of the above Fuzzy AHP steps would provide the results of green indicators, sub-indicators, and firms' activities (alternatives) for implementing green SCM in Pakistan. 
Table 4. Random index (RI) scale for each matrix.

\begin{tabular}{ccc}
\hline $\boldsymbol{n}$ & $\boldsymbol{R \boldsymbol { I } _ { \boldsymbol { m } }}$ & $\boldsymbol{R \boldsymbol { I } _ { \boldsymbol { g } }}$ \\
\hline 1 & 0 & 1 \\
2 & 0 & 2 \\
3 & 0.4890 & 0.1796 \\
4 & 0.7937 & 0.2627 \\
5 & 1.0720 & 0.3597 \\
6 & 1.1996 & 0.3818 \\
7 & 1.2874 & 0.4090 \\
8 & 1.3410 & 0.4164 \\
9 & 1.3793 & 0.4348 \\
10 & 1.4095 & 0.4455 \\
\hline
\end{tabular}

\section{Results and Discussion}

In the study, a hybrid decision framework (i.e., a Delphi and Fuzzy AHP) has been used to analyze actual garment manufacturing firms. In the case study, the firms are required to improve and transform the manufacturing process into green activities to obey the environmental management regulations and SCM. Therefore, to deal with the problem of supplier selection, the firm should adopt green SCM indicators or criteria to follow the environmental regulations. This decision methodology outlines a systematic and feasible approach for managers towards evaluating and ranking six important green indicators for supply chain operations. Initially, the results of the Fuzzy AHP method has been utilized to evaluate six green indicators (criteria), and twenty-two sub-indicators (sub-criteria), and three firms (alternatives) for the adoption of green SCM practices.

\subsection{Case Information}

Due to the increasing prosperity of the garment products and network market, the manufacturing firms are producing at large scale to meet consumer demand [63]. Currently, several firms produce the largest share of professional garment manufacturing products in Pakistan and these firms are also the largest exporters of the country. The firms are continuing to develop next-generation technology (i.e., Industry 4.0) for improving their competitiveness and satisfying customer demand [64,65]. Furthermore, a rapid transforming of garment manufacturing to green SCM activities is occurring, such as product design, production, purchasing etc. The firms are continuing to develop new green technologies and green products to comply with the environmental regulations of the government. Thus, for the firm to sustain in a competitive market, a proper green SCM system is very important.

It is essential to understand the role of green SCM practices for the sustainable manufacturing process in the firms. Therefore, this study develops the firms' green SCM indicators and sub-indicators to transform the firms' activities into green activities. In the study, three garment manufacturing firms were analyzed. The experts identified a systematic procedure for assessing the green SCM practices of the firms. To select the significant firm, this study, therefore implemented the decision methodology, and firms were evaluated with respect to proposed green indicators for SCM operations. The analysis obtained in this study would provide suggestions to the firms, and it would also be very useful for effective and efficient green SCM adoption process.

\subsection{Results of Fuzzy AHP Method}

The Fuzzy AHP approach has been carried out to determine the various green indicators and sub-indicators weights with respect to the decision methodology of the study. Ten experts' opinions were undertaken to analyze the results. Therefore, in this study, the group decision-making approach has been used to obtain the final results of green SCM indicators and sub-indicators in the context of Pakistan. The detailed fuzzy pairwise comparisons matrix of the indicators and sub-indicators with 
respect to the goal is presented in Appendix B. In the following section, the results of the Fuzzy AHP method have been analyzed.

\subsubsection{Ranking of Green Indicators}

Table 5 presents the weights and ranking of indicators for green SCM practices in Pakistan. The results of the present study show that green purchasing (G2) with a weight of 0.253 is the most important indicator for the sustainable development of green SCM practices in the country. The second-ranked most important indicator was green design (G1) with a weight of 0.228 , while other ranks in the following order: green production (G3) with a weight of 0.192, green logistics (G5) with a weight of 0.152 , reverse logistics (G6) with a weight of 0.106 , and green warehousing (G4) with a weight of 0.069 . Finally, this ranking evaluated the importance of each indicator for the sustainable implementation of green SCM practices in Pakistan.

Table 5. The indicators (criteria) results with respect to the goal.

\begin{tabular}{cccc}
\hline Code & Indicators (Criteria) & Weight & Rank \\
\hline G1 & Green design & 0.228 & 2nd \\
G2 & Green purchasing & 0.253 & $1 \mathrm{st}$ \\
G3 & Green production & 0.192 & 3rd \\
G4 & Green warehousing & 0.069 & 6 th \\
G5 & Green logistics & 0.152 & 4 th \\
G6 & Reverse logistics & 0.106 & 5th \\
\hline
\end{tabular}

\subsubsection{Ranking of Sub-Indicators (Green Design)}

Figure 2 depicts the weights and ranking of sub-indicators with respect to green design (G1). In the classification of sub-indicators, it is identified that eco-design products (G11) with a weight of 0.373 is the most significant sub-indicator for the implementation of green design products in green SCM practices. Reuse and recycle the product (G14) and reduce the consumption of materials (G13) are recognized as second and third important sub-indicators with a weight of 0.288 and 0.228 . Meanwhile, reducing the use of hazardous products (G12) is identified as the least important sub-indicator with respect to green design. Finally, for the sustainable development of green SCM practices in Pakistan, it is necessary to determine green design sub-indicators.

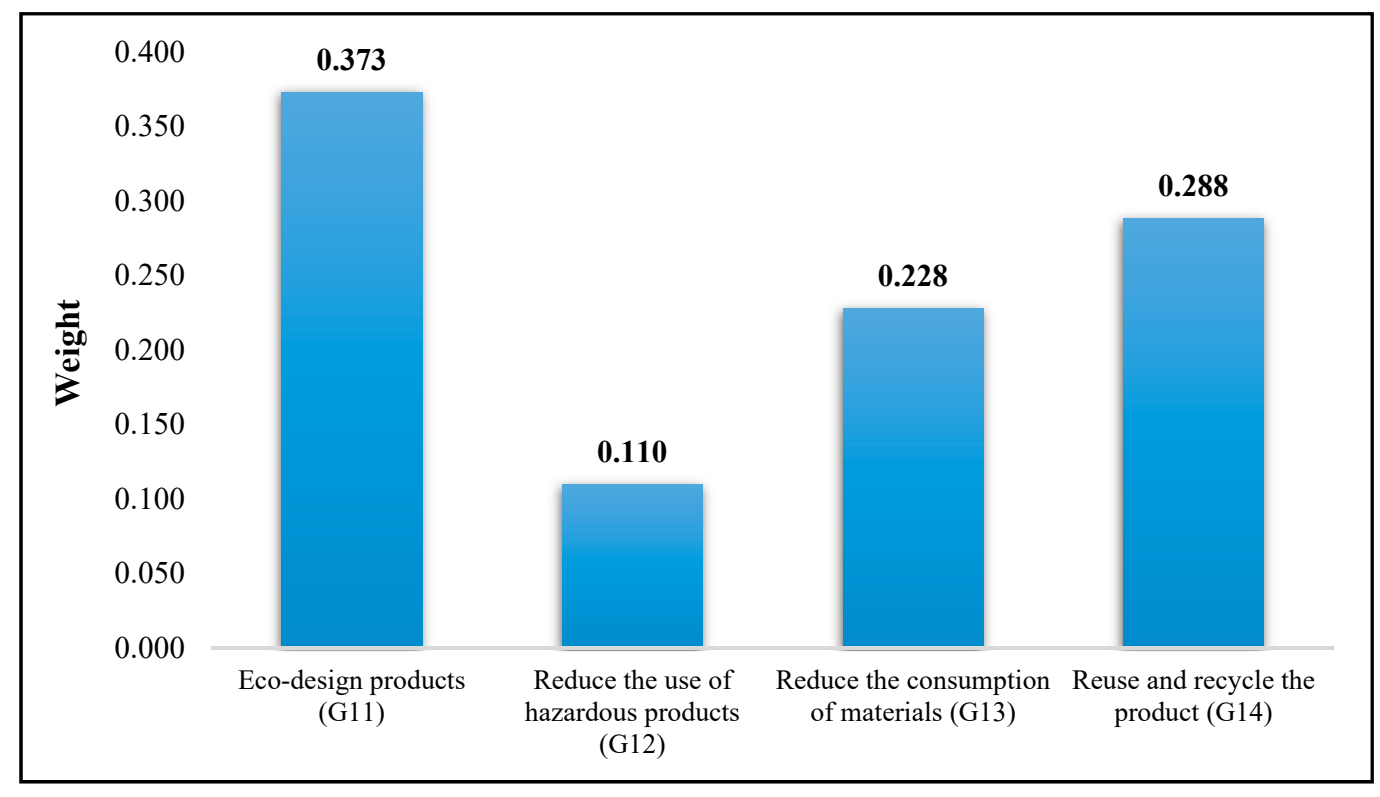

Figure 2. The sub-indicators results with respect to the green design (G1). 


\subsubsection{Ranking of Sub-Indicators (Green Purchasing)}

Figure 3 depicts the weights and ranking of sub-indicators with respect to green purchasing (G2). The first place in the ranking of the sub-indicators is to select the eco-friendly supplier (G21) with a weight of 0.429 is first ranked sub-criteria for the evaluation of green SCM practices in the country. Meanwhile, pushing suppliers to take eco-friendly actions (G23) and purchase of eco-friendly raw materials (G22) with a weight of 0.356 and 0.215 are considered as second and third important sub-indicator in the perspective of green SCM in Pakistan.

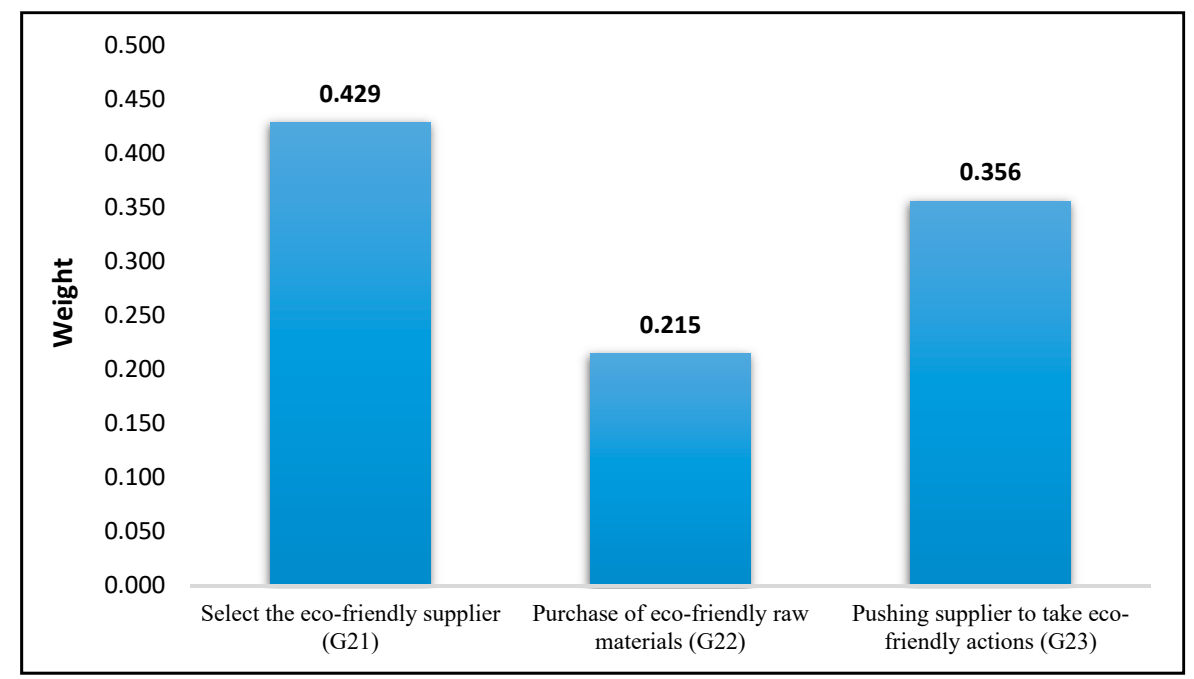

Figure 3. The sub-indicators results with respect to green purchasing (G2).

\subsubsection{Ranking of Sub-Indicators (Green Production)}

Figure 4 presents the weights and ranking of sub-indicators with respect to green production (G3). In the ranking of the sub-indicators, cleaner production (G31) is identified as a significant sub-indicator with a weight of 0.411 for the evaluation of green SCM practices in the country. Further, reduce the environmental impact on operations (G33), and lean production (G32) are also best-suited sub-indicators with a weight of 0.328 and 0.183 . Reduce the amount of scrap (G34) is determined as the least significant sub-indicator. In the study, all these sub-indicators are crucial for the development of green CSM practices in Pakistan.

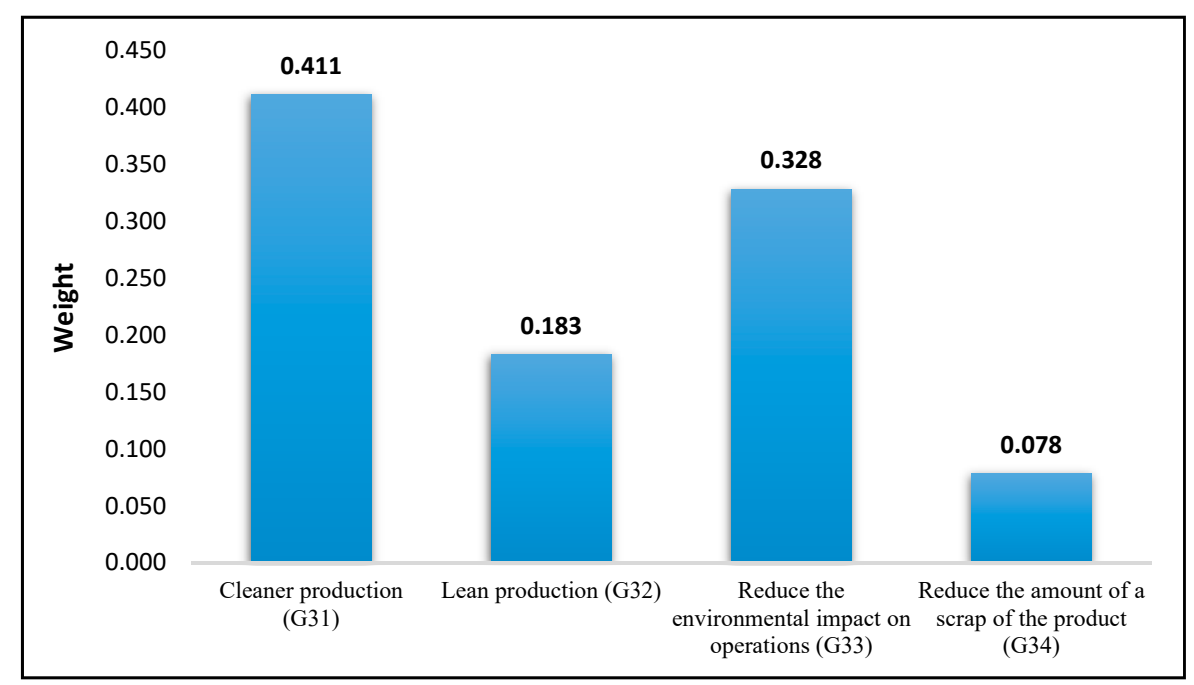

Figure 4. The sub-indicators results with respect to green production (G3). 


\subsubsection{Ranking of Sub-Indicators (Green Warehousing)}

Figure 5 presents the weights and ranking of sub-indicators with respect to green warehousing (G4). In the G4 category, eco-packaging (G41) was prioritized as the top-ranked sub-indicator with a weight of 0.373 . The following sub-indicators were prioritized: reducing the inventory levels (G43), sale of excess inventories (G42), and sale of scrap materials (G44), respectively. Therefore, the key steps must be taken by managers and governments to analyze the indictors for implementing green SCM practices.

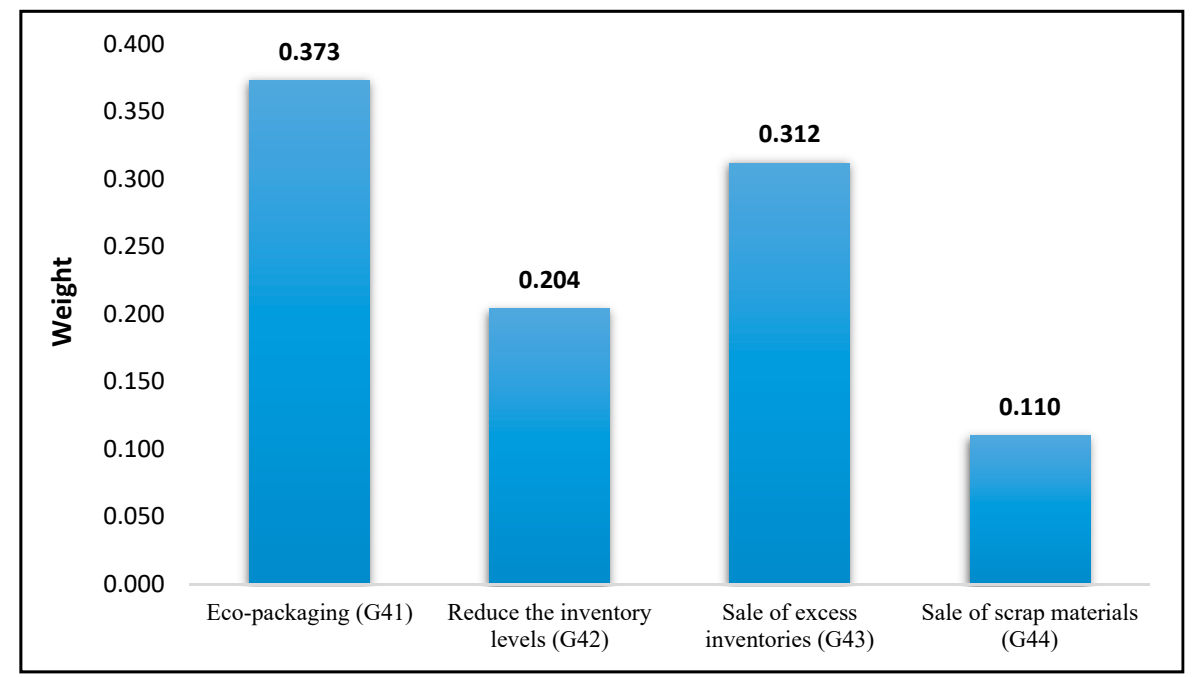

Figure 5. The sub-indicators results with respect to the green warehousing (G4).

\subsubsection{Ranking of Sub-Indicators (Green Logistics)}

Figure 6 illustrates the weights and ranking of sub-indicators with respect to green logistics (G5). The results indicate that using eco-friendly transportation (G52) is an optimal sub-indicator with a weight of 0.417 for carrying out the green SCM practices in Pakistan. Meanwhile, eco-friendly distribution (G53) with a weight of 0.347 is recognized as the second important sub-indicator in the perspective of green logistics; reduce fuel consumption (G51) is considered as the least significant sub-indicator for the development of sustainable green activities in SCM.

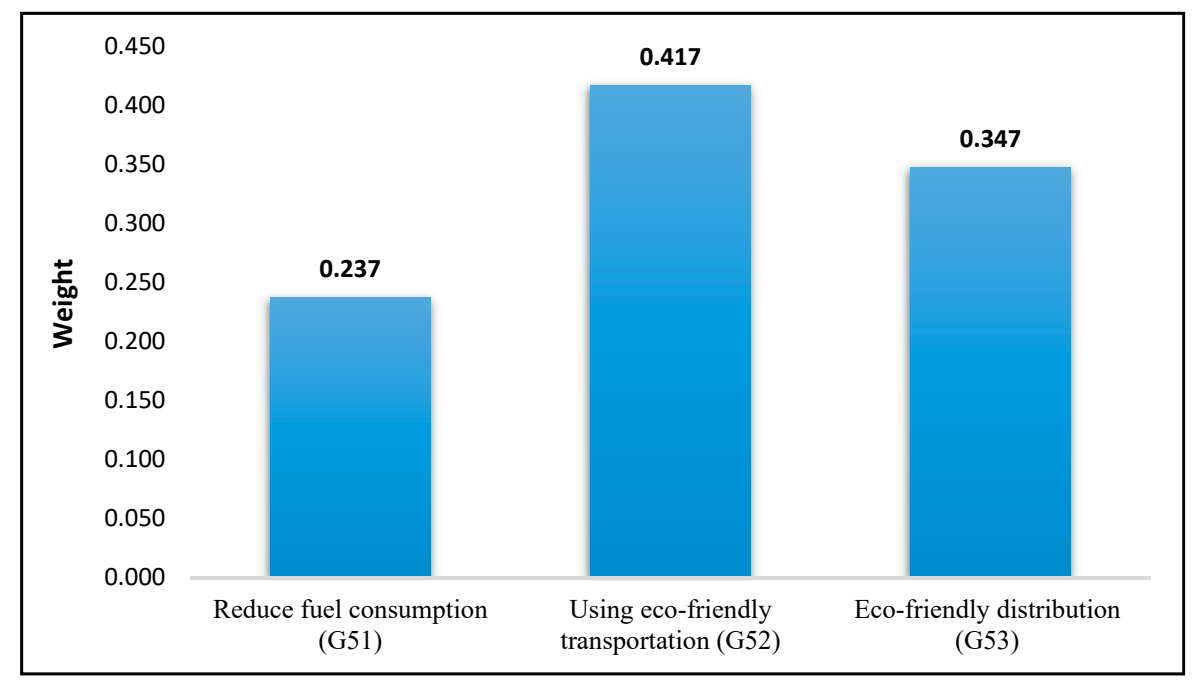

Figure 6. The sub-indicators results with respect to green logistics (G5). 


\subsubsection{Ranking of Sub-Indicators (Reverse Logistics)}

Figure 7 indicates the weights and ranking of sub-indicators with respect to reverse logistics (G6). Develop an environmental management system (G61) was prioritized as the most influential sub-indicator with a weight of 0.382. The use of alternative energy sources (G62) is ranked as the second important sub-indicator, while recycling end-of-life products (G63), and use of waste of other industries (G64) followed as third and fourth, respectively.

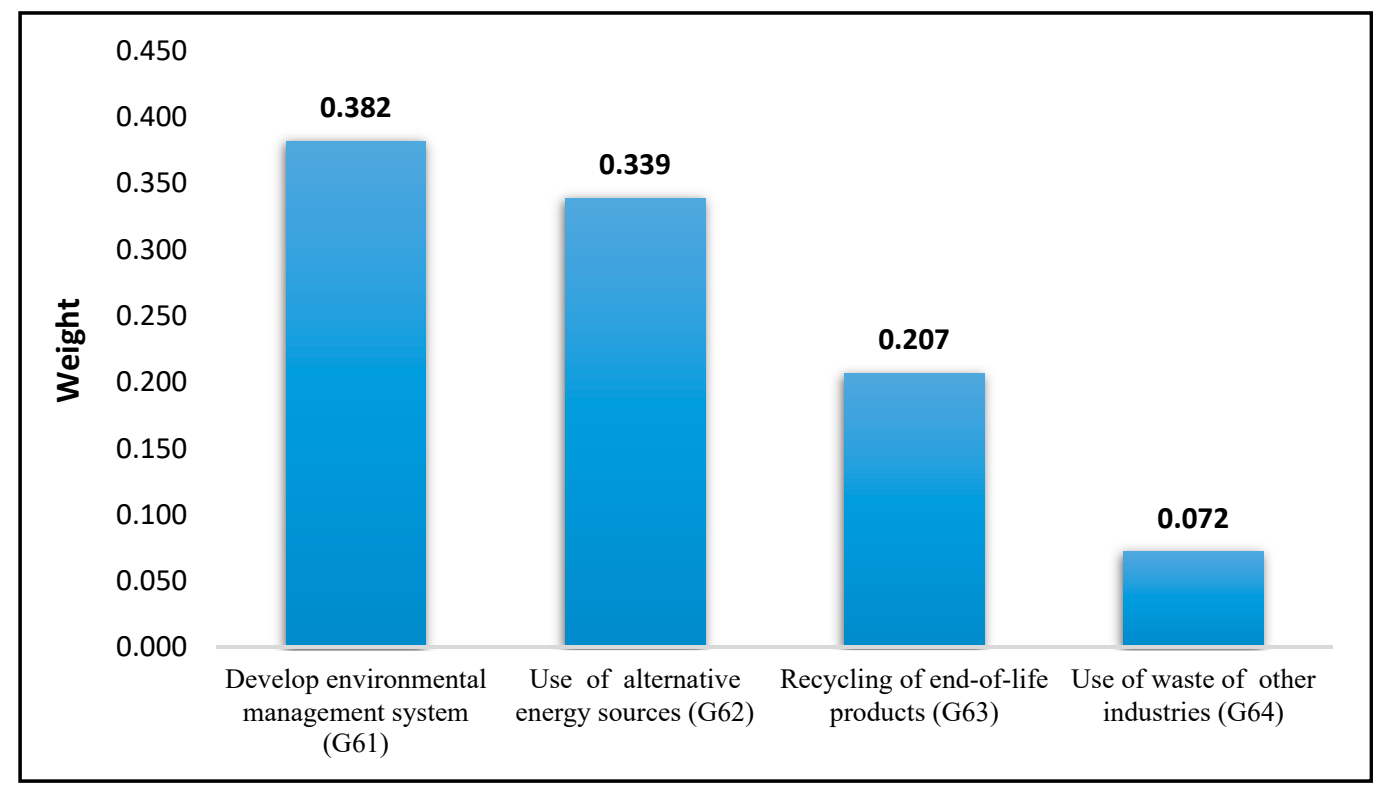

Figure 7. The sub-indicators results with respect to the reverse logistics (G6).

\subsection{Ranking of Overall Sub-Indicators}

Table 6 presents the overall ranking of green sub-indicators with respect to the goal. Overall, twenty-two sub-indicators were analyzed for the evaluation of green SCM practices. The results indicate that "select the eco-friendly supplier (G21)", "pushing supplier to take eco-friendly actions (G23)", and "eco-design products (G11)" are the most significant sub-indicators (sub-criteria), while "sale of excess inventories (G42)", "use of waste of other industries (G64)", and "sale of scrap materials (G44)" are considered as most insignificant sub-indicators for the development and adoption of green SCM practices in Pakistan.

\subsection{Ranking of Manufacturing Firms (Alternatives)}

The above section provides the results of six green indicators and twenty-two sub-indicators, while in this section, the three manufacturing firms (alternatives) results have been analyzed using the Fuzzy AHP method. Figure 8 presents the final ranking order of alternatives with respect to the goal. In the study, the names of the firms are not disclosed due to privacy to the implementation of green SCM activities. Experts' analysis assisted in obtaining consistent and reliable results for the Fuzzy AHP approach. The results indicate that the garment manufacturing firm (F1) is identified as the most significant option for the development of green SCM practices. While F2 is recognized as a second suitable option, while F3 is considered as a third important firm in the adoption of green supply practices in Pakistan. 
Table 6. The weights and ranking of overall sub-indicators.

\begin{tabular}{llcc}
\hline Code & \multicolumn{1}{c}{ Sub-Indicator (Sub-Criteria) } & Weight & Rank \\
\hline G21 & Select the eco-friendly supplier & 0.1085 & 1 st \\
G23 & Pushing supplier to take eco-friendly actions & 0.0900 & 2nd \\
G11 & Eco-design products & 0.0850 & 3rd \\
G31 & Cleaner production & 0.0789 & 4 th \\
G14 & Reuse and recycle the product & 0.0656 & 5 th \\
G52 & Using eco-friendly transportation & 0.0633 & 6 th \\
G33 & Reduce the environmental impact on operations & 0.0629 & 7 th \\
G22 & Purchase of eco-friendly raw materials & 0.0543 & 8th \\
G53 & Eco-friendly distribution & 0.0527 & 9 th \\
G13 & Reduce the consumption of materials & 0.0519 & 10 th \\
G61 & Develop environmental management system & 0.0404 & 11th \\
G51 & Reduce fuel consumption & 0.0360 & 12 th \\
G62 & Use of alternative energy sources & 0.0359 & 13th \\
G32 & Lean production & 0.0351 & 14th \\
G41 & Eco-packaging & 0.0257 & 15 th \\
G12 & Reduce the use of hazardous products & 0.0250 & 16th \\
G63 & Recycling of end-of-life products & 0.0219 & 17th \\
G43 & Reduce the inventory levels & 0.0215 & 18th \\
G34 & Reduce the amount of scrap & 0.0149 & 19th \\
G42 & Sale of excess inventories & 0.0140 & 20th \\
G64 & Use of waste of other industries & 0.0076 & 21st \\
G44 & Sale of scrap materials & 0.0075 & 22nd \\
\hline & & &
\end{tabular}

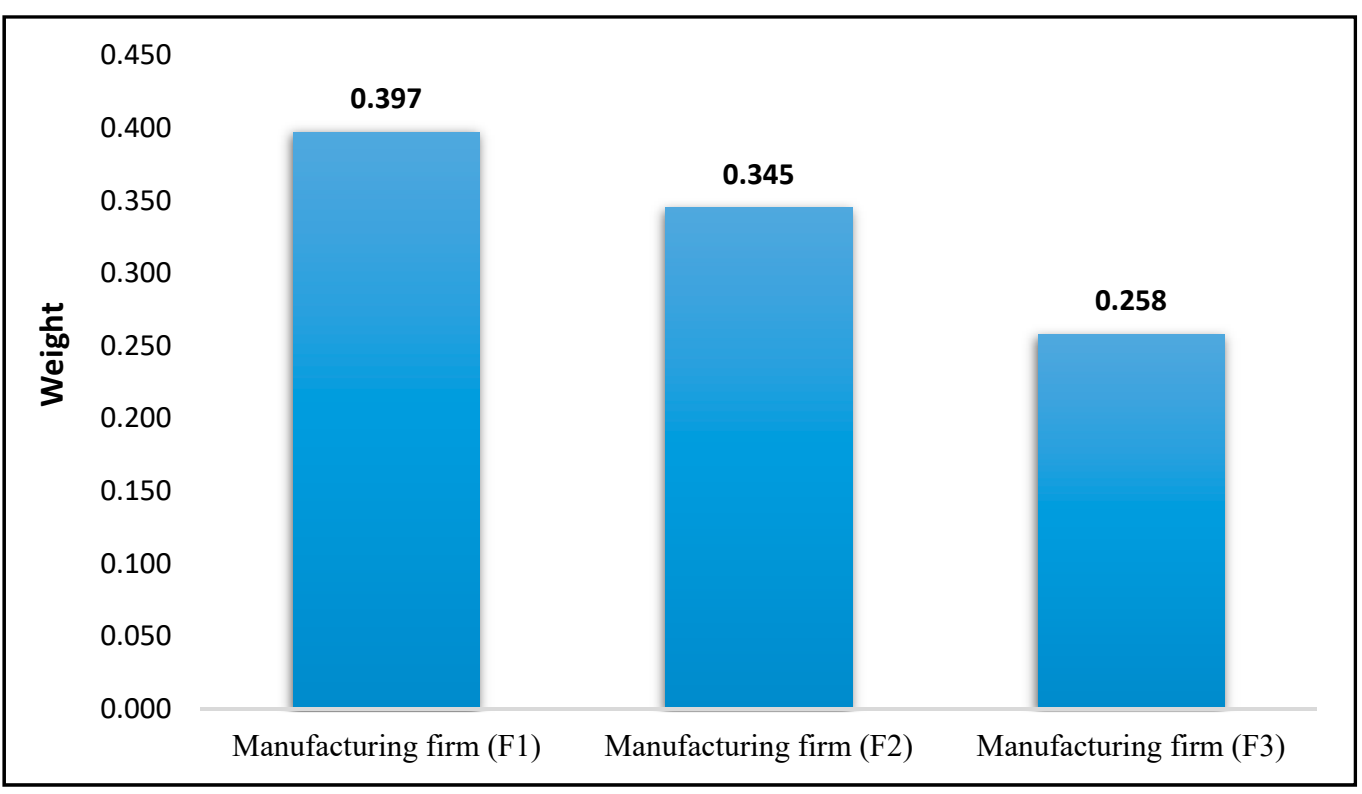

Figure 8. The final ranking of manufacturing firms (alternatives).

\subsection{Discussion}

In the study, three garment manufacturing firms of Pakistan were selected as a case study. Each of the firms has been evaluated with proposed green indicators and sub-indicators for implementing sustainable SCM practices. The proposed decision methodology has been successfully applied to this complex decision problem. The results indicated that the manufacturing firm (F1) is the most optimal in performing and implementing green activities in the firm. Additionally, the results of Fuzzy AHP methodology recommended that green indicators revealed that green purchasing (G2) with 0.253 placed in the first priority, green design (G1) with 0.228 in the second place, green production (G3) with 0.192 in the third place, green logistics (G5) with 0.152 in the fourth place, reverse logistics (G6) with 
0.106 in the fifth place, and green warehousing (G4) with 0.069 acquired the lowest importance. Further, the five most important green indicators are selecting the eco-friendly supplier, pushing supplier to take eco-friendly actions, eco-design products, cleaner production, and reuse and recycle the product.

This is the first study that identifies and assesses the green indicators for supply chain activities in Pakistan. However, there are various studies pertaining to the evaluation of green SCM with different aims and objectives. The findings of $\mathrm{Wu}$ et al. [30], shows that environmental policy objectives and top-level management support are very important factors for shifting of any firm to sustainable SCM operations, they also indicate that green purchasing is the most important factor in supply management operations. The study by Tseng et al. [32] found that supplier involvement and process control are the two important aspects for determining the close-loop hierarchical structure in green SCM; these findings are very similar to this study in which the selecting eco-friendly supplier is recognized as the most important green sub-indicator for SCM practices The results of the case study are similar to Deng et al. [35], who found that green purchasing and green design are the most important green criteria for evaluating the firm activities toward sustainable SCM. The results of this study are also in line with Korrakot et al. [36], who indicated that green procurement is the most optimal green driver for implementing the green SCM practices. Moreover, the results are partially similar to the study of Chen et al. [33], who investigated the business strategy for green SCM using ANP method and found that green design, green purchasing, and green manufacturing are the significant green strategies for SCM activities. In a broader sense, the decision methodology can be utilized as an analytical approach to propose and select a strategic environmental development plan for green SCM practices of the firms. To obtain significant results, managers should understand the firms' green SCM assessment indicators. In this study, it is identified that none of the previous studies used a Delphi and Fuzzy AHP model to evaluate green indicators and sub-indicators for assessing firms' green SCM practices in the context of Pakistan.

The developed decision methodology is validated through the case study of Pakistan, and the manufacturing companies (alternatives) were assessed in a fuzzy environment considering uncertainty and vagueness of real-life cases. There are various studies, which investigate the green performance of the firms, but, in this study, the Fuzzy AHP methodology is used for assessing and prioritizing the overall green SCM practices of the firms. The assessment procedure enables firms to check their green practices comparing the other firms and to determine useful opinion about the areas of improvement. This study, therefore, would greatly guide managers and governments to initiate green SCM practices in the country.

\section{Conclusions}

In this study, green SCM practices have been evaluated from the perspective of Pakistan. The main aim of this study was to develop important indicators to analyze the green SCM practices using the Delphi and Fuzzy AHP methodologies. Thus, this is a very first attempt and research work to evaluate green SCM practices for minimizing the negative impact of supply chain operation on the environment. The industries have to improve their ability to adopt green activities based on environmental regulations and practices. This study contributes to green SCM practices and developed significant indicators based on the literature review. Therefore, the various important and validated indicators were determined for the successful implementation of green SCM in the country. To achieve sustainable development goals, it is necessary for a country to focus on green practices. The various studies have comprehensively discussed the basics of green SCM implementation practices; however, nowadays, this is a very critical topic, and more research work is needed to explore and analyze the development of green SCM practices in Pakistan. 
The decision making and evaluation process in real-life is often difficult to understand because the numerous uncertainties and fuzziness exist. This research has developed a systematic decision framework methodology comprises of a Delphi and Fuzzy AHP methods to evaluate the green indicators for handling vague and inconsistent data appropriately. This study has selected three garment manufacturing firms to conduct further research. The Fuzzy AHP results identified that green purchasing (G2), green design (G1), and green production (G3) are the most important indicators for the adoption of green SCM practices in Pakistan. While green logistic (G5), reverse logistics (G6), and green warehousing (G4) are considered as the least important indicators for the development of green SCM. Moreover, the leading sub-indicator in green SCM practices were G21, G23, and G11. Afterwards, the results of the alternatives reveal that $\mathrm{F} 1$ is the most optimal manufacturing firm for the sustainable implementation of green SCM practices in Pakistan. The F2 and F3 ranked as second and third important firms in adoption to green practices. This decision-making process would assist managers in analyzing and selecting the optimal firm for green practices in Pakistan.

\subsection{Managerial Implications}

A hybrid decision methodology has been developed to evaluate the green practices with respect to GSM. The firms can derive advantage from the decision methodology developed in the study, which can be employed as a roadmap to a consensus understanding to assess firms' activities in green SCM. Based on the findings of this study, with the green evaluation tool developed, now firms can determine the various ways to enhance green practices and reduce environmental impacts. Thus, managers can develop a resilient relationship with their partners, depending on their strengths and take necessary actions to overcome the weaknesses. The digitalization of the firms can be possible by adopting Industry 4.0 approaches and sustainability-related issues for systematically analyzing the decision problem. Moreover, the results of the study can also assist managers in selecting the finest green SCM partner for future cooperation and collaboration. Therefore, the results of the study are very significant for implementing the developed decision framework in green production practices.

\subsection{Limitations and Future Research Work}

This research has several key limitations. For instance, the managers of the firms did not participate in the study due to difficulties in approaching and accessing them. Therefore, in future research, top-level managers can be employed in the decision-making process, which shall improve the consistency and robustness of the proposed research framework. Another limitation is that this study used Fuzzy AHP method; however, it is also essential to use other MCDM techniques such as ANP, DEA, VIKOR, DEMATEL, and ELECTRE to compare the results of the proposed framework and also analyze the decision problem as a case studies on supply chain practices. This is an outline for future research. This study provides a base for proposing green indicators and implementing green SCM activities in the context of Pakistani firms. Additionally, in future research, the horizontal integration of supply chain management practices should be undertaken with Industry 4.0 and environmental sustainability-related issues to analyze the decision problem more comprehensively.

Author Contributions: Conceptualization, L.X.; methodology, Y.Z.; validation, G.M.S.; formal analysis, Y.Z.; investigation, L.X. and G.M.S.; writing—original draft preparation, Y.Z.; writing—review and editing, L.X. and G.M.S.

Funding: This paper received no external funding.

Conflicts of Interest: The authors declare no conflict of interest. 
Appendix A Questionnaire Survey on "Evaluating and Ranking of Green SCM Practices and Performances of Manufacturing Firms in Pakistan"

Table A1. The detailed information of the experts.

\begin{tabular}{|c|c|c|c|c|c|c|}
\hline $\begin{array}{l}\text { Number of } \\
\text { Experts }\end{array}$ & Designation & Gender & Age & Education & Work Experience & Organization \\
\hline 1 & Professor & Male & 45 & $\mathrm{PhD}$ & 15 years & University of Sindh, Jamshoro, Pakistan \\
\hline 1 & Associate Professor & Male & 40 & $\mathrm{PhD}$ & 7 years & $\begin{array}{l}\text { Quaid-Awam University of Engineering, Science, and } \\
\text { Technology, Nawabshah, Pakistan }\end{array}$ \\
\hline 1 & Associate Professor & Male & 42 & $\mathrm{PhD}$ & 8 years & $\begin{array}{l}\text { Mehran University of Engineering and Technology, } \\
\text { Jamshoro, Pakistan }\end{array}$ \\
\hline 1 & Research fellow & Male & 45 & Masters & 12 years & Pakistan Institutes of Development Economics \\
\hline 1 & Research fellow & Female & 35 & Masters & 4 years & $\begin{array}{l}\text { Logistics and Supply Chain Management Department, } \\
\text { NUST, Islamabad }\end{array}$ \\
\hline 1 & Research fellow & Female & 40 & $\mathrm{PhD}$ & 8 years & Supply Chain Management, IBA, Karachi \\
\hline 1 & Stakeholder & Male & 55 & Bachelors & 20 years & Supply Chain Association of Pakistan \\
\hline 1 & Stakeholder & Female & 40 & Masters & 10 years & Supply Chain Association of Pakistan \\
\hline 1 & Analyst & Male & 50 & $\mathrm{PhD}$ & 15 years & Pakistan Institute of Management, Islamabad \\
\hline 1 & Analyst & Female & 35 & Masters & 12 years & Pakistan Institute of Management, Islamabad \\
\hline
\end{tabular}


Table A2. Please rate your opinion on a 5-point Likert scale on the following indicators in terms of their importance in evaluating and prioritizing green SCM practices in Pakistan.

\begin{tabular}{|c|c|c|c|c|c|}
\hline \multirow{2}{*}{ Green SCM Indicators and Sub-Indicators } & Extremely Important & Very Important & Neutral & Low Important & Not at all Important \\
\hline & 5 & 4 & 3 & 2 & 1 \\
\hline \multicolumn{6}{|l|}{ Green design (G1) } \\
\hline \multicolumn{6}{|l|}{ Eco-design products (G11) } \\
\hline \multicolumn{6}{|l|}{ Reduce the use of hazardous products (G12) } \\
\hline \multicolumn{6}{|l|}{ Reduce the consumption of materials (G13) } \\
\hline \multicolumn{6}{|l|}{ Reuse and recycle the product (G14) } \\
\hline \multicolumn{6}{|l|}{ Green purchasing (G2) } \\
\hline \multicolumn{6}{|l|}{ Select the eco-friendly supplier (G21) } \\
\hline \multicolumn{6}{|l|}{ Purchase of eco-friendly raw materials (G22) } \\
\hline \multicolumn{6}{|l|}{ Pushing supplier to take eco-friendly actions (G23) } \\
\hline \multicolumn{6}{|l|}{ Green production (G3) } \\
\hline \multicolumn{6}{|l|}{ Cleaner production (G31) } \\
\hline \multicolumn{6}{|l|}{ Lean production (G32) } \\
\hline \multicolumn{6}{|l|}{ Reduce the environmental impact on operations (G33) } \\
\hline \multicolumn{6}{|l|}{ Reduce the amount of scrap (G34) } \\
\hline \multicolumn{6}{|l|}{ Green warehousing (G4) } \\
\hline \multicolumn{6}{|l|}{ Eco-packaging (G41) } \\
\hline \multicolumn{6}{|l|}{ Sale of excess inventories (G42) } \\
\hline \multicolumn{6}{|l|}{ Reduce the inventory levels (G43) } \\
\hline \multicolumn{6}{|l|}{ Sale of scrap materials (G44) } \\
\hline \multicolumn{6}{|l|}{ Green logistics (G5) } \\
\hline \multicolumn{6}{|l|}{ Reduce fuel consumption (G51) } \\
\hline \multicolumn{6}{|l|}{ Using eco-friendly transportation (G52) } \\
\hline \multicolumn{6}{|l|}{ Eco-friendly distribution (G53) } \\
\hline \multicolumn{6}{|l|}{ Reverse logistics (G6) } \\
\hline \multicolumn{6}{|l|}{ Develop environmental management system (G61) } \\
\hline \multicolumn{6}{|l|}{ Use of alternative energy sources (G62) } \\
\hline \multicolumn{6}{|l|}{ Recycling of end-of-life products (G63) } \\
\hline Use of waste of other industries (G64) & & & & & \\
\hline
\end{tabular}


Table A3. Additional green SCM indicators relating to the problem mentioned above, if any.

$$
\begin{aligned}
& \text { Green design (G1) } \\
& \text { Green purchasing (G2) } \\
& \text { Green production (G3) } \\
& \text { Green warehousing (G4) } \\
& \text { Green logistics (G5) } \\
& \text { Reverse logistics (G6) }
\end{aligned}
$$

\section{Appendix B Pairwise Comparison Matrix of Fuzzy AHP Method}

Table A4. Fuzzy pairwise comparison matrix with respect to the goal.

\begin{tabular}{ccccccccc}
\hline & G1 & G2 & G3 & G4 & G5 & G6 & Weight & Rank \\
\hline G1 & $(1.000,1.000,1.000)$ & $(0.333,0.758,1.000)$ & $(1.000,1.149,3.000)$ & $(1.000,2.992,6.000)$ & $(1.000,2.766,4.000)$ & $(1.000,3.103,5.000)$ & 0.228 & 2 nd \\
\hline G2 & $(1.000,1.319,3.003)$ & $(1.000,1.000,1.000)$ & $(1.000,2.408,4.000)$ & $(2.000,3.519,6.000)$ & $(2.000,3.519,6.000)$ & $(2.000,3.322,6.000)$ & 0.253 & 1 st \\
\hline G3 & $(0.333,0.870,1.000)$ & $(0.250,0.415,1.000)$ & $(1.000,1.000,1.000)$ & $(1.000,2.551,4.000)$ & $(1.000,1.741,3.000)$ & $(1.000,2.352,4.000)$ & 0.192 & 3 rd \\
\hline G4 & $(0.167,0.334,1.000)$ & $(0.167,0.284,0.500)$ & $(0.250,0.392,1.000)$ & $(1.000,1.000,1.000)$ & $(0.250,0.392,1.000)$ & $(0.333,0.758,1.000)$ & 0.069 & 6 th \\
\hline G5 & $(0.250,0.362,1.000)$ & $(0.167,0.284,0.500)$ & $(0.333,0.574,1.000)$ & $(1.000,2.551,4.000)$ & $(1.000,1.000,1.000)$ & $(1.000,1.516,3.000)$ & 0.152 & 4 th \\
\hline G6 & $(0.200,0.322,1.000)$ & $(0.167,0.301,0.500)$ & $(0.250,0.425,1.000)$ & $(1.000,1.319,3.003)$ & $(0.333,0.660,1.000)$ & $(1.000,1.000,1.000)$ & 0.106 & 5 th \\
\hline
\end{tabular}

$$
\mathrm{CR}_{\mathrm{m}}=0.034 \text { and } \mathrm{CR}_{\mathrm{g}}=0.0858 \text {. }
$$

Table A5. Fuzzy pairwise comparison matrix with respect to the green design (G1).

\begin{tabular}{ccccccc}
\hline & G11 & G12 & G13 & G14 & Weight & Rank \\
\hline G11 & $(1.000,1.000,1.000)$ & $(2.000,3.680,6.000)$ & $(1.000,2.929,5.000)$ & $(1.000,1.644,4.000)$ & 0.373 & 1 st \\
\hline G12 & $(0.167,0.272,0.500)$ & $(1.000,1.000,1.000)$ & $(0.250,0.608,1.000)$ & $(0.250,0.393,1.000)$ & 0.110 & 4 th \\
\hline G13 & $(0.200,0.341,1.000)$ & $(1.000,1.645,4.000)$ & $(1.000,1.000,1.000)$ & $(0.333,0.660,1.000)$ & 0.228 & 3 rd \\
\hline G14 & $(0.250,0.608,1.000)$ & $(1.000,2.545,4.000)$ & $(1.000,1.515,3.003)$ & $(1.000,1.000,1.000)$ & 0.288 & 2nd \\
\hline \multicolumn{7}{c}{ CR $_{m}=0.0208$ and $\mathrm{CR}_{\mathrm{g}}=0.0506}$. \\
\multicolumn{3}{c}{}
\end{tabular}

Table A6. Fuzzy pairwise comparison matrix with respect to the green purchasing (G2).

\begin{tabular}{cccccc}
\hline & G21 & G22 & G23 & Weight & Rank \\
\hline G21 & $(1.000,1.000,1.000)$ & $(1.000,2.408,4.000)$ & $(1.000,1.431,4.000)$ & 0.429 & $1 \mathrm{st}$ \\
G22 & $(0.250,0.415,1.000)$ & $(1.000,1.000,1.000)$ & $(0.250,0.608,1.000)$ & 0.215 & 3rd \\
G23 & $(0.250,0.699,1.000)$ & $(1.000,1.645,4.000)$ & $(1.000,1.000,1.000)$ & 0.356 & 2nd \\
\hline
\end{tabular}

$$
\mathrm{CR}_{\mathrm{m}}=0.007 \text { and } \mathrm{CR}_{\mathrm{g}}=0.0152 \text {. }
$$

Table A7. Fuzzy pairwise comparison matrix with respect to the green production (G3).

\begin{tabular}{ccccccc}
\hline & G31 & G32 & G33 & G34 & Weight & Rank \\
\hline G31 & $(1.000,1.000,1.000)$ & $(2.000,3.000,4.000)$ & $(1.000,1.516,3.000)$ & $(2.000,3.681,6.000)$ & 0.411 & 1st \\
\hline G32 & $(0.250,0.333,0.500)$ & $(1.000,1.000,1.000)$ & $(0.250,0.488,1.000)$ & $(1.000,1.516,3.000)$ & 0.183 & 3rd \\
\hline G33 & $(0.333,0.660,1.000)$ & $(1.000,2.049,4.000)$ & $(1.000,1.000,1.000)$ & $(1.000,2.550,4.000)$ & 0.328 & 2nd \\
\hline G34 & $(0.167,0.272,0.500)$ & $(0.333,0.660,1.000)$ & $(0.250,0.392,1.000)$ & $(1.000,1.000,1.000)$ & 0.078 & 4th \\
\hline
\end{tabular}

$$
\mathrm{CR}_{\mathrm{m}}=0.0198 \text { and } \mathrm{CR}_{\mathrm{g}}=0.0456 \text {. }
$$

Table A8. Fuzzy pairwise comparison matrix with respect to the green warehousing (G4).

\begin{tabular}{ccccccc}
\hline & G41 & G42 & G43 & G44 & Weight & Rank \\
\hline G41 & $(1.000,1.000,1.000)$ & $(1.000,2.551,4.000)$ & $(1.000,2.000,3.000)$ & $(2.000,3.519,6.000)$ & 0.373 & 1 st \\
\hline G42 & $(0.250,0.392,1.000)$ & $(1.000,1.000,1.000)$ & $(0.250,0.609,1.000)$ & $(1.000,1.320,3.000)$ & 0.204 & 3rd \\
\hline G43 & $(0.333,0.500,1.000)$ & $(1.000,1.642,4.000)$ & $(1.000,1.000,1.000)$ & $(1.000,2.930,5.000)$ & 0.312 & 2nd \\
\hline G44 & $(0.167,0.284,0.500)$ & $(0.333,0.758,1.000)$ & $(0.200,0.341,1.000)$ & $(1.000,1.000,1.000)$ & 0.110 & 4th \\
\hline \multicolumn{7}{c}{$\mathrm{CR}_{\mathrm{m}}=0.023$ and $\mathrm{CR}_{\mathrm{g}}=0.0516}$. \\
\multicolumn{7}{c}{}
\end{tabular}


Table A9. Fuzzy pairwise comparison matrix with respect to the green logistics (G5).

\begin{tabular}{cccccc}
\hline & G51 & G52 & G53 & Weight & Rank \\
\hline G51 & $(1.000,1.000,1.000)$ & $(0.250,0.562,1.000)$ & $(0.333,0.758,1.000)$ & 0.237 & 3rd \\
G52 & $(1.000,1.779,4.000)$ & $(1.000,1.000,1.000)$ & $(1.000,1.320,3.000)$ & 0.417 & 1st \\
G53 & $(1.000,1.319,3.003)$ & $(0.333,0.758,1.000)$ & $(1.000,1.000,1.000)$ & 0.347 & 2nd \\
\hline
\end{tabular}

$\mathrm{CR}_{\mathrm{m}}=0.0056$ and $\mathrm{CR}_{\mathrm{g}}=0.0152$.

Table A10. Fuzzy pairwise comparison matrix with respect to the reverse logistics (G6).

\begin{tabular}{ccccccc}
\hline & G611 & G62 & G63 & G64 & Weight & Rank \\
\hline G61 & $(1.000,1.000,1.000)$ & $(1.000,1.149,3.000)$ & $(1.000,2.551,4.000)$ & $(2.000,3.898,6.000)$ & 0.382 & 1 st \\
\hline G62 & $(0.333,0.870,1.000)$ & $(1.000,1.000,1.000)$ & $(1.000,2.170,4.000)$ & $(2.000,3.000,4.000)$ & 0.339 & 2 nd \\
\hline G63 & $(0.250,0.392,1.000)$ & $(0.250,0.461,1.000)$ & $(1.000,1.000,1.000)$ & $(1.000,1.516,3.000)$ & 0.207 & 3 rd \\
\hline G64 & $(0.167,0.257,0.500)$ & $(0.250,0.333,0.500)$ & $(0.333,0.660,1.000)$ & $(1.000,1.000,1.000)$ & 0.072 & 4 th \\
\hline \multicolumn{7}{c}{$\mathrm{CR}_{\mathrm{m}}=0.0174$ and $\mathrm{CR}_{\mathrm{g}}=0.0464}$. \\
\multicolumn{7}{c}{}
\end{tabular}

\section{References}

1. Lin, R.J. Using Fuzzy DEMATEL to Evaluate the Green Supply Chain Management Practices. J. Clean. Prod. 2013, 40, 32-39. [CrossRef]

2. Kannan, D.; De Sousa Jabbour, A.B.L.; Jabbour, C.J.C. Selecting Green Suppliers Based on GSCM Practices: Using Fuzzy TOPSIS Applied to a Brazilian Electronics Company. Eur. J. Oper. Res. 2014, 233, $432-447$. [CrossRef]

3. Haji Vahabzadeh, A.; Asiaei, A.; Zailani, S. Reprint of "Green Decision-Making Model in Reverse Logistics Using FUZZY-VIKOR Method". Resour. Conserv. Recycl. 2015, 104, 334-347. [CrossRef]

4. Green, K.W.; Zelbst, P.J.; Bhadauria, V.S.; Meacham, J. Do Environmental Collaboration and Monitoring Enhance Organizational Performance? Ind. Manag. Data Syst. 2012, 112, 186-205. [CrossRef]

5. Diabat, A.; Govindan, K. An Analysis of the Drivers Affecting the Implementation of Green Supply Chain Management. Resour. Conserv. Recycl. 2011, 55, 659-667. [CrossRef]

6. Sinaga, O.; Mulyati, Y.; Darrini, A.; Galdeano, D.M.; Prasetya, A.R. Green Supply Chain Management Organizational Performance. Int. J. Supply Chain Manag. 2019, 8, 76-85.

7. Ali, S.; Xu, H.; Ahmed, W.; Ahmad, N.; Solangi, Y.A. Metro Design and Heritage Sustainability: Conflict Analysis Using Attitude Based on Options in the Graph Model. Environment, Development and Sustainability. Available online: https://link.springer.com/article/10.1007/s10668-019-00365-w (accessed on 7 May 2019).

8. Stock, T.; Seliger, G. Opportunities of Sustainable Manufacturing in Industry 4.0. Procedia CIRP 2016, 40, 536-541. [CrossRef]

9. Manavalan, E.; Jayakrishna, K. A Review of Internet of Things (IoT) Embedded Sustainable Supply Chain for Industry 4.0 Requirements. Comput. Ind. Eng. 2019, 127, 925-953. [CrossRef]

10. Luthra, S.; Mangla, S.K. Evaluating Challenges to Industry 4.0 Initiatives for Supply Chain Sustainability in Emerging Economies. Process Saf. Environ. Prot. 2018, 117, 168-179. [CrossRef]

11. Mills, S. Discourse: The New Critical Idiom; Routledge: London, UK; New York, NY, USA, 1997.

12. Pfohl, H.-C.; Yahsi, B.; Kersten, W.; Blecker, T.; Ri, C.M. The Impact of Industry Supply Chain. Proceedings of the Hamburg International. In Innovations and Strategies for Logistics and Supply Chains, Proceedings of the Hamburg International Conference of Logistics; Epubli: Berlin, Germany, 2015; pp. 31-58.

13. Kiel, D.; Müller, J.M.; Arnold, C.; Voigt, K.I. Sustainable Industrial Value Creation: Benefits and Challenges of Industry 4.0. Int. J. Innov. Manag. 2017, 21, 1740015. [CrossRef]

14. Stock, T.; Obenaus, M.; Kunz, S.; Kohl, H. Industry 4.0 as Enabler for a Sustainable Development: A Qualitative Assessment of Its Ecological and Social Potential. Process Saf. Environ. Prot. 2018, 118, 254-267. [CrossRef]

15. Govindan, K.; Kannan, D.; Mathiyazhagan, K.; Jabbour, A.B.L.D.S.; Jabbour, C.J.C. Analysing Green Supply Chain Management Practices in Brazil's Electrical/Electronics Industry Using Interpretive Structural Modelling. Int. J. Environ. Stud. 2013, 70, 477-493. [CrossRef] 
16. Wu, C.; Barnes, D. An Integrated Model for Green Partner Selection and Supply Chain Construction. J. Clean. Prod. 2016, 112, 2114-2132. [CrossRef]

17. Kannan, D.; Khodaverdi, R.; Olfat, L.; Jafarian, A.; Diabat, A. Integrated Fuzzy Multi Criteria Decision Making Method and Multiobjective Programming Approach for Supplier Selection and Order Allocation in a Green Supply Chain. J. Clean. Prod. 2013, 47, 355-367. [CrossRef]

18. Tseng, M.L. Green Supply Chain Management with Linguistic Preferences and Incomplete Information. Appl. Soft Comput. J. 2011, 11, 4894-4903. [CrossRef]

19. Bouzon, M.; Govindan, K.; Rodriguez, C.M.T.; Campos, L.M.S. Identification and Analysis of Reverse Logistics Barriers Using Fuzzy Delphi Method and AHP. Resour. Conserv. Recycl. 2016, 108, 182-197. [CrossRef]

20. Cheng, J.H.; Lee, C.M.; Tang, C.H. An Application of Fuzzy Delphi and Fuzzy AHP on Evaluating Wafer Supplier in Semiconductor Industry. WSEAS Trans. Inf. Sci. Appl. 2009, 6, 756-767.

21. Hsu, Y.L.; Lee, C.H.; Kreng, V.B. The Application of Fuzzy Delphi Method and Fuzzy AHP in Lubricant Regenerative Technology Selection. Expert Syst. Appl. 2010, 37, 419-425. [CrossRef]

22. De Oliveira, U.R.; Espindola, L.S.; da Silva, I.R.; da Silva, I.N.; Rocha, H.M. A Systematic Literature Review on Green Supply Chain Management: Research Implications and Future Perspectives. J. Clean. Prod. 2018, 187, 537-561. [CrossRef]

23. Zhu, Q.; Sarkis, J.; Lai, K. Green Supply Chain Management Innovation Diffusion and Its Relationship to Organizational Improvement: An Ecological Modernization Perspective. J. Eng. Technol. Manag. 2012, 29, 168-185. [CrossRef]

24. Rao, P.; Holt, D. Do Green Supply Chains Lead to Competitiveness and Economic Performance? Int. J. Oper. Prod. Manag. 2005, 25, 898-916. [CrossRef]

25. Solangi, Y.A.; Tan, Q.; Mirjat, N.H.; Ali, S. Evaluating the Strategies for Sustainable Energy Planning in Pakistan: An Integrated SWOT-AHP and Fuzzy-TOPSIS Approach. J. Clean. Prod. 2019, 236, 117655. [CrossRef]

26. Stojčić, M.; Zavadskas, E.K.; Pamučar, D.; Stević, Ž.; Mardani, A. Application of MCDM Methods in Sustainability Engineering: A Literature Review 2008-2018. Symmetry 2019, 11, 350. [CrossRef]

27. Solangi, Y.A.; Tan, Q.; Khan, M.W.A.; Mirjat, N.H.; Ahmed, I. The Selection of Wind Power Project Location in the Southeastern Corridor of Pakistan: A Factor Analysis, AHP, and Fuzzy-TOPSIS Application. Energies 2018, 11, 1940. [CrossRef]

28. Gandhi, S.; Mangla, S.K.; Kumar, P.; Kumar, D. A Combined Approach Using AHP and DEMATEL for Evaluating Success Factors in Implementation of Green Supply Chain Management in Indian Manufacturing Industries. Int. J. Logist. Res. Appl. 2016, 19, 537-561. [CrossRef]

29. Shen, L.; Muduli, K.; Barve, A. Developing a Sustainable Development Framework in the Context of Mining Industries: AHP Approach. Resour. Policy 2015, 46, 15-26. [CrossRef]

30. Wu, H.H.; Chang, S.Y. A Case Study of Using DEMATEL Method to Identify Critical Factors in Green Supply Chain Management. Appl. Math. Comput. 2015, 256, 394-403. [CrossRef]

31. Govindan, K.; Muduli, K.; Devika, K.; Barve, A. Investigation of the Influential Strength of Factors on Adoption of Green Supply Chain Management Practices: An Indian Mining Scenario. Resour. Conserv. Recycl. 2016, 107, 185-194. [CrossRef]

32. Tseng, M.L.; Lin, R.J.; Lin, Y.H.; Chen, R.H.; Tan, K. Close-Loop or Open Hierarchical Structures in Green Supply Chain Management under Uncertainty. Expert Syst. Appl. 2014, 41, 3250-3260. [CrossRef]

33. Chen, C.C.; Shih, H.S.; Shyur, H.J.; Wu, K.S. A Business Strategy Selection of Green Supply Chain Management via an Analytic Network Process. Comput. Math. Appl. 2012, 64, 2544-2557. [CrossRef]

34. Uygun, Ö.; Dede, A. Performance Evaluation of Green Supply Chain Management Using Integrated Fuzzy Multi-Criteria Decision Making Techniques. Comput. Ind. Eng. 2016, 102, 502-511. [CrossRef]

35. Deng, H.; Luo, F.; Wibowo, S. Multi-Criteria Group Decision Making for Green Supply Chain Management under Uncertainty. Sustainability 2018, 10, 3150. [CrossRef]

36. Tippayawong, K.Y.; Niyomyat, N.; Sopadang, A.; Ramingwong, S. Factors Affecting Green Supply Chain Operational Performance of the Thai Auto Parts Industry. Sustainability 2016, 8, 1161. [CrossRef]

37. Eltayeb, T.K.; Zailani, S.; Ramayah, T. Green Supply Chain Initiatives among Certified Companies in Malaysia and Environmental Sustainability: Investigating the Outcomes. Resour. Conserv. Recycl. 2011, 55, 495-506. [CrossRef] 
38. Tseng, M.L.; Chiu, A.S.F. Evaluating Firm's Green Supply Chain Management in Linguistic Preferences. J. Clean. Prod. 2013, 40, 22-31. [CrossRef]

39. Laosirihongthong, T.; Adebanjo, D.; Choon Tan, K. Green Supply Chain Management Practices and Performance. Ind. Manag. Data Syst. 2013, 113, 1088-1109. [CrossRef]

40. Kumar, A.; Jain, V.; Kumar, S. A Comprehensive Environment Friendly Approach for Supplier Selection. Omega 2014, 42, 109-123. [CrossRef]

41. Awasthi, A.; Chauhan, S.S.; Goyal, S.K. A Fuzzy Multicriteria Approach for Evaluating Environmental Performance of Suppliers. Int. J. Prod. Econ. 2010, 126, 370-378. [CrossRef]

42. Govindan, K.; Rajendran, S.; Sarkis, J.; Murugesan, P. Multi Criteria Decision Making Approaches for Green Supplier Evaluation and Selection: A Literature Review. J. Clean. Prod. 2015, 98, 66-83. [CrossRef]

43. Mathiyazhagan, K.; Govindan, K.; Noorul Haq, A. Pressure Analysis for Green Supply Chain Management Implementation in Indian Industries Using Analytic Hierarchy Process. Int. J. Prod. Res. 2014, 52, 188-202. [CrossRef]

44. Choudhary, M.; Seth, N. Integration of Green Practices in Supply Chain Environment The Practices of Inbound, Operational, Outbound and Reverse Logistics. Int. J. Eng. Sci. Technol. 2011, 3, 4985-4992.

45. Kafa, N.; Hani, Y.; El Mhamedi, A. Sustainability Performance Measurement for Green Supply Chain Management. IFAC Proc. Vol. 2013, 6, 71-78. [CrossRef]

46. Lin, R.-J.; Chen, R.-H.; Nguyen, T.-H. Green Supply Chain Management Performance in Automobile Manufacturing Industry under Uncertainty. Procedia-Soc. Behav. Sci. 2011, 25, 233-245. [CrossRef]

47. Seth, D.; Rehman, M.A.A.; Shrivastava, R.L. Green Manufacturing Drivers and Their Relationships for Small and Medium(SME) and Large Industries. J. Clean. Prod. 2018, 198, 1381-1405. [CrossRef]

48. Ray, C.D.; Laddad, A.; Ventura, J.A. The Impact of Cutting Bill Variability on Product Flow for a Hardwood Dimension Mill as Determined through Discrete Event Simulation. Wood Fiber Sci. 2007, 39, 614-627.

49. Zhu, Q.; Geng, Y.; Fujita, T.; Hashimoto, S. Green Supply Chain Management in Leading Manufacturers: Case Studies in Japanese Large Companies. Manag. Res. Rev. 2010, 33, 380-392. [CrossRef]

50. Green, K.W.; Zelbst, P.J.; Meacham, J.; Bhadauria, V.S. Green Supply Chain Management Practices: Impact on Performance. Supply Chain Manag. 2012, 17, 290-305. [CrossRef]

51. Wan, S.P.; Wang, Q.Y.; Dong, J.Y. The Extended VIKOR Method for Multi-Attribute Group Decision Making with Triangular Intuitionistic Fuzzy Numbers. Knowl. Based Syst. 2013, 52, 65-77. [CrossRef]

52. Wan Mahmood, W.H.; Ab Rahman, M.N.; Md Deros, B.; Jusoff, K.; Saptari, A.; Ebrahim, Z.; Mohamed Sultan, A.A.; Abu Bakar, M.H.; Subramonian, S.; Jano, Z. Manufacturing Performance in Green Supply Chain Management. World Appl. Sci. J. 2013, 21, 76-84.

53. Prentkovskis, O.; Erceg, Ž.; Stević, Ž.; Tanackov, I.; Vasiljević, M.; Gavranović, M. A New Methodology for Improving Service Quality Measurement: Delphi-FUCOM-SERVQUAL Model. Symmetry 2018, 10, 757. [CrossRef]

54. Bernal, R.; San-Jose, L.; Retolaza, J.L. Improvement Actions for a More Social and Sustainable Public Procurement: A Delphi Analysis. Sustainability 2019, 11, 4069. [CrossRef]

55. Mahajan, V.; Linstone, H.A.; Turoff, M. The Delphi Method: Techniques and Applications. J. Mark. Res. 1976, 13, 317. [CrossRef]

56. Stewart, T.R. The Delphi Technique and Judgmental Forecasting. Clim. Chang. 1987, 11, 97-113. [CrossRef]

57. Solangi, Y.A.; Tan, Q.; Mirjat, N.H.; Valasai, G.D.; Khan, M.W.A.; Ikram, M. An Integrated Delphi-AHP and Fuzzy TOPSIS Approach toward Ranking and Selection of Renewable Energy Resources in Pakistan. Processes 2019, 7, 118. [CrossRef]

58. Chou, Y.C.; Yen, H.Y.; Dang, V.T.; Sun, C.C. Assessing the Human Resource in Science and Technology for Asian Countries: Application of Fuzzy AHP and Fuzzy TOPSIS. Symmetry 2019, 11, 251. [CrossRef]

59. Yazdani-Chamzini, A.; Shariati, S.; Yakhchali, S.H.; Zavadskas, E.K. Proposing a New Methodology for Prioritising the Investment Strategies in the Private Sector of Iran. Econ. Res. Istraz. 2014, 27, 320-345. [CrossRef]

60. Leśniak, A.; Kubek, D.; Plebankiewicz, E.; Zima, K.; Belniak, S. Fuzzy AHP Application for Supporting Contractors' Bidding Decision. Symmetry 2018, 10, 642. [CrossRef]

61. Kaganski, S.; Majak, J.; Karjust, K. Fuzzy AHP as a Tool for Prioritization of Key Performance Indicators. Procedia CIRP 2018, 72, 1227-1232. [CrossRef] 
62. Gogus, O.; Boucher, T.O. Strong Transitivity, Rationality and Weak Monotonicity in Fuzzy Pairwise Comparisons. Fuzzy Sets Syst. 1998, 94, 133-144. [CrossRef]

63. Yasmeen, H.; Wang, Y.; Zameer, H.; Solangi, Y.A. Does Oil Price Volatility Influence Real Sector Growth? Empirical Evidence from Pakistan. Energy Rep. 2019, 5, 688-703. [CrossRef]

64. Nagy, J.; Oláh, J.; Erdei, E.; Máté, D.; Popp, J. The Role and Impact of Industry 4.0 and the Internet of Things on the Business Strategy of the Value Chain-the Case of Hungary. Sustainability 2018, 10, 3491. [CrossRef]

65. Piccarozzi, M.; Aquilani, B.; Gatti, C. Industry 4.0 in Management Studies: A Systematic Literature Review. Sustainability 2018, 10, 3821. [CrossRef]

(C) 2019 by the authors. Licensee MDPI, Basel, Switzerland. This article is an open access article distributed under the terms and conditions of the Creative Commons Attribution (CC BY) license (http://creativecommons.org/licenses/by/4.0/). 